\title{
Acaricidal Activity of Plant Extracts and Their Main Terpenoids on The Two- Spotted Spider Mite Tetranychus Urticae (Acari: Tetranychidae)
}

\author{
Hamdy A. Eldoksch ${ }^{1}$, Farida A. Ayad ${ }^{1}$ and Abdel-Khalek H. El-Sebae ${ }^{2}$
}

\begin{abstract}
The acaricidal activity of certain natural plant extracts and some of their main terpenoids was evaluated against the female adults of the two-spotted spider mite, Tetranychus urticae (Koch) under laboratory conditions using the slide dip and surface residue techniques. The relationship between chemical structure of terpenes and acaricidal efficacy was evaluated. The results revealed that peppermint, thyme, caraway and clove extracts were the most effective against the spider mite, followed by chenopodium and visnaga extracts and then eucalyptus and sweet basil which showed relatively the least miticidal activity. Of the terpenoids tested, the monoterpene hydrocarbons limonene and ocimene were completely ineffective on the mite at all concentrations tested, whereas, the oxygenated terpene alcohols menthol and linalool exhibited promising acaricidal activity. The phenolic compound thymol was the most active among tested terpenoids followed by carvone, a monocyclic ketone and the main constituent of caraway oil and proved to be biologically more active against mites than camphor (the bicyclic monoterpene ketone).Visnagin, a furanochromone with one methoxy group, was significantly more toxic against adult spider mite than khellin which has two methoxy groups. The results obtained suggest that certain terpenoids of plant origin can be used as potential parent structures for new acaricides and as alternative and safe acaricidal agents.
\end{abstract}

Keywords: Natural acaricide, plant extracts, terpenoids, two-spotted spider mite, Tetranychus urticae Koch.

\section{INTRODUCTION}

Tetranychid mite, Tetranychus urticae Koch. is a major pest to the economic field crops, vegetables, fruits and ornamental plants causing severe damage to vegetative growth, seeds and crop quality (El-Sebae $e t$ al., 1978; Ismail and Hoda, 1985; Osman et al., 1985; Eldoksch et al., 1991a; Hosny et al., 2003 and Miresmailli et al., 2006). Spider mite control, generally, depends on the use of synthetic acaricides that led to increasing environmental problems including mite resistance, persistent residues, hazardous effects on non-target organisms and human health hazards. Therefore, it is necessary to find out more selective and safe materials to be used for mite control. Methods of

\footnotetext{
${ }^{1}$ Central Agricultural Pesticides Laboratory, Agricultural Research Center, Dokki, Giza, Egypt.

${ }^{2}$ Pesticide Chemistry Dept., Fac. of Agric., Alex. Univ., El-Shatby,

Alexandria, Egypt.

Received July12, 2009, Accepted August 16, 2009
}

pesticide screening rely on random testing of numerous chemical analogues against various pests to identify new leading molecules for fungicide, acaricide or insecticide synthesis. An emerging alternative to random chemical synthesis is the study and exploitation of naturally occurring products with pesticidal activities to identify such leading molecules (Pillmoor et al., 1993 and Brent, 1996). Research on natural products and essential oils derived from plants has led to exploring many of biologically active chemicals useful in plant protection mainly against insect pests, weeds and plant pathogenic fungi and bacteria (Saleh et al., 1984; Bowers, 1985; Duke, 1986; El-Sebae, 1987; Bentley et al., 1988; Eldoksch et al., 1996; Eldoksch et al., 1997; Eldoksch et al., 2001 and Eldoksch and El-Sebae, 2005). The present study was conducted to investigate the acaricidal activity of certain plant extracts and oils and some of their major components against the twospotted spider mite, Tetranychus urticae (Koch) under laboratory conditions which could enable a determination of the necessary structures for their acaricidal action and to predict the possible structureactivity relationships.

\section{MATERIALS AND METHODS}

\section{Tested plant extracts and terpenoids}

Eight plant extracts and ten of their major components were tested for acaricidal activity studies. The tested plants were: caraway, Carum carvi L. (fruits); peppermint, Mentha piperita L. (leaves); thyme, Thymus vulgaris L. (leaves); blue gum, Eucalyptus globulus (leaves); visnaga, Ammi visnaga (fruits); sweet basil, Ocimum basilicum (leaves); chenopodium, C. ambrosiodes (leaves) and clove, Eugenia caryophyllus (buds). The terpenoids tested (Fig. 1) were simple hydrocarbons (limonene, ocimene), alcohols (linalool, menthol), phenols (thymol, eugenol), ketones (carvone, camphor), furanochromones (khellin, visnagin). Khellin and visnagin were provided by Memphis Pharmacutical Company; menthol, thymole and camphor were purchased from Algomhoria Company for Drugs \& Medicinal Survices. Carvone was provided by Polak and Schwarz's EssenceFabrieken, Zaandam, Holland. The rest of 
monoterpenes were provided by Fluka. Vertimec $1.8 \%$

(E.C.) with active ingredient, abamectin is a

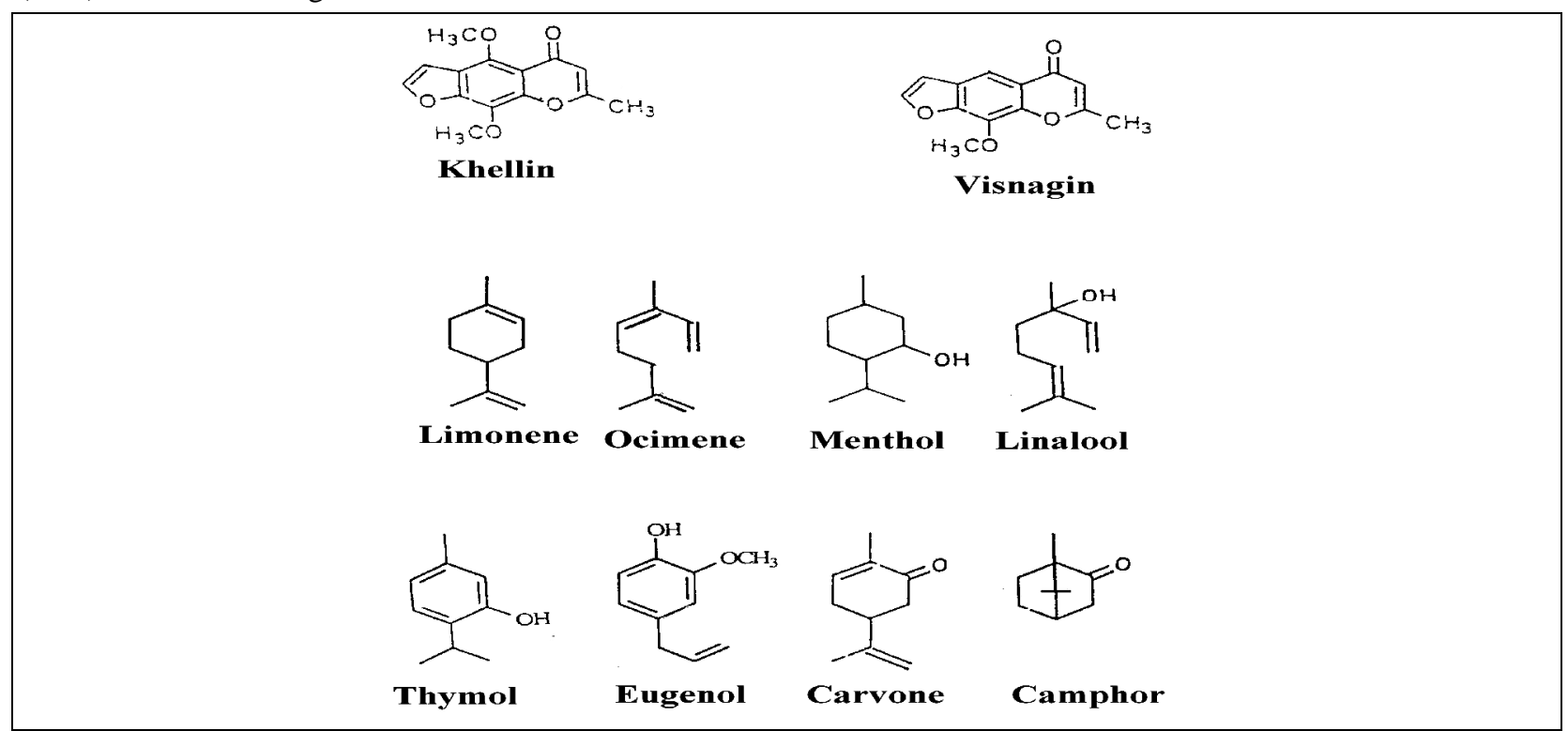

\section{Figure 1. Chemical structures of tested furanochromones and monoterpenes}

naturally derived product was provided by the Central Agricultural Pesticide Laboratory (CAPL) and used as a reference for comparison.

\section{Preparation of extracts}

The extraction of plant materials was carried out according to Meisner et al.(1981). Samples of about 150-200 g each of dried plant material were ground into fine powder and extracted by soaking for five days in $80 \%$ ethanol $(2 \times 1.5 \mathrm{~L})$. The combined ethanol extract was filtered and concentrated under reduced pressure at $45-50^{\circ} \mathrm{C}$ and then it was partitioned with petroleum ether $(3 \times 300 \mathrm{ml})$. The petroleum ether extract was concentrated and evaporated to dryness to obtain the oily crude extracts.

\section{Bioassay techniques}

\section{Slide dip technique}

The slide dip method described by Dittrich (1962) was used to evaluate the acaricidal activity of plant extracts and terpenoids. The prepared slides containing adult females of the two-spotted spider mites T. urticae (20 mites/slide) were dipped in the tested solution for five seconds. Three replicates were made for each concentration. Mortality counts were recorded $48 \mathrm{hrs}$ after treatment. The tested mites were obtained from mite culture reared on lima bean plants.

\section{Surface residue technique}

A filter paper contact bioassay was used to evaluate the toxicity of plant extracts and terpenoids to T. urticae (Stendel and Fuchs, 1984). $0.5 \mathrm{ml}$ of acetone containing the tested concentration was applied to a filter paper
$(5.25 \mathrm{~cm}$ in diameter) placed at the bottom of a Petri dish (6 $\mathrm{cm}$ in diameter). After the solvent was evaporated, ten adult females of $T$. urticae were introduced in each Petri dish. The control Petri dish with filter paper received $0.5 \mathrm{ml}$ acetone and 10 adult female mites. Mortality counts were recorded $48 \mathrm{hrs}$ after treatment. The treated mites were kept under constant conditions, at $27^{\circ} \mathrm{C}$ and $60-70 \%$ relative humidity. Mites were counted as dead if no irritability was observed after stroking them with a fine hair brush using a stereoscopic microscope. The $\mathrm{LC}_{50}$ values (lethal concentrations that cause $50 \%$ mortality of the treated population), their confidence limits and slope values for the different plant extracts and terpenoids were calculated using Litchfield and Wilcoxon (1949) method and Finney (1971).

\section{RESULTS AND DISCUSSIONS}

\section{Acaricidal efficacy of plant extracts}

The acaricidal activity of eight plant extracts was evaluated against adult females of the two spotted spider mite T. urticae and presented in Table (1) in terms of $\mathrm{LC}_{50} \mathrm{~s}$, their confidence limits and slope values. The data in Table (1) indicate that by using the slide dip technique, the clove and thyme extracts were the most toxic against the spider mite with $\mathrm{LC}_{50} \mathrm{~s}$ of 470 and 556 ppm, respectively, followed by peppermint extract (725 ppm), caraway (800 ppm), and chenopodium (930 ppm). Sweet basil, visnaga and eucalyptus (blue gum) extracts came next in their acaricidal activity with $\mathrm{LC}_{50} \mathrm{~s}$ of 1175,3150 and $4600 \mathrm{ppm}$, respectively. The 
standard acaricide vertimec exhibited high acaricidal activity to the two-spotted spider mite with $\mathrm{LC}_{50}$ value of $145 \mathrm{ppm}$.

Table 1. Toxicity of crude plant extracts against adult females of the two-spotted spider mite, Tetranychus urticae (Koch) using the slide dip technique

\begin{tabular}{lcccc}
\hline \multicolumn{1}{c}{ Plant extracts } & $\begin{array}{c}\mathbf{L C}_{\mathbf{5 0}} \\
(\mathbf{p p m})\end{array}$ & Confidence limits for $\mathbf{L C}_{\mathbf{5 0}}$ & Slope value & Toxicity index \\
\hline Clove & 470 & $(427.3-517.0)$ & 2.14 & 30.8 \\
Peppermint & 725 & $(659.1-797.5)$ & 1.88 & 20.0 \\
Caraway & 800 & $(727.2-880.0)$ & 2.13 & 18.1 \\
Thyme & 556 & $(505.4-611.6)$ & 2.84 & 26.1 \\
Chenopodium & 930 & $(845.4-1023.0)$ & 2.06 & 15.6 \\
Sweet basil & 1175 & $(1068.2-1292.5)$ & 1.85 & 12.3 \\
Eucalyptus (blue gum) & 4600 & $(4181.8-5060.0)$ & 1.77 & 3.1 \\
Visnaga & 3150 & $(2889.9-3433.5)$ & 2.35 & 4.6 \\
\hline Vertimec (acaricide) & 145 & $(131.6-159.5)$ & 2.86 & 100 \\
\hline
\end{tabular}

The promising acaricidal activity that was exhibited by some plant extracts against adult mites in the present work may be due to such active compounds present in the crude extracts of the selected medicinal plants (Bouwmeester et al., 1998 and Eldoksch and El-Sebae, 2005).

\section{Acaricidal efficacy of terpenoids}

Results in Table (2) indicated that the monoterpene hydrocarbons, either cyclic (i.e., limonene) or alicyclic (i.e., ocimene) (Fig. 1) did not show any acaricidal activity up to $10000 \mathrm{ppm}$ using the two different bioassay methods applied (Tables 2 and 3). In contrast, the terpene alcohols, menthol and linalool exhibited promising acaricidal activity with $\mathrm{LC}_{50}$ values of 640 and $920 \mathrm{ppm}$, respectively in case of slide dip technique and 580 and $2150 \mathrm{ppm}$ in case of surface residue technique. Therefore, the oxygenated functional groups can potentiate the acaricidal efficacy among these compounds. Thymol, the main compound of thyme, gave high acaricidal activity in each of slide dip and surface residue techniques with $\mathrm{LC}_{50}$ values of 465 and 413 ppm, respectively. Also, eugenol, the main compound of clove showed promising acaricidal activity with $\mathrm{LC}_{50}$ values of 580 and $865 \mathrm{ppm}$, respectively. This potent acaricidal efficacy of thymol and eugenol may be due to a phenolic function which can enhance the miticidal characteristics of terpenes. Carvone, a monocyclic ketone and the main component of caraway oil (Bouwmeester et al., 1998), revealed also potent acaricidal activity in both slide dip and surface residue techniques with $\mathrm{LC}_{50}$ values of 575 and $525 \mathrm{ppm}$, respectively. On the other hand, the acaricidal activity of camphor, a bicyclic monoterpene ketone and the main component of blue gum, E. glubulus, showed moderate

acaricidal activity with $\mathrm{LC}_{50}$ values of 4250 and 3830 ppm in both slide dip and surface residue assays, respectively. It is of interest to mention that the monoterpene, carvone which exhibited potent acaricidal efficacy in the present work has previously been reported by several investigators to have diverse biological activity against certain human pathogenic bacteria and fungi (Sivropoulou et al., 1995 and Naigre et al., 1996), against phytopathogenic fungi and bacteria (Eldoksch and Abdel-Moity, 1997; Hassanein and Eldoksch, 1997; Eldoksch and Hassanein, 2007) and also against agricultural insects (Meisner et al., 1982; Eldoksch et al., 1991b and Hamaad et al., 2008)).

The data also showed that khellin and visnagin, the main compounds of visnaga extract, showed acaricidal activity with some differences in their efficacy against the tested mite (Tables 2 and 3). The results indicated that a furanocromone visnagin which has one methoxy group (Figure1) exhibited reasonable acaricidal activity after $48 \mathrm{~h}$ of treatment in both the slide dip and surface residue techniques with $\mathrm{LC}_{50}$ values of 748 and 540 ppm, respectively. Khellin, which is structurally close to visnagin but has two methoxy groups, showed moderate acaricidal activity in both bioassay methods giving $\mathrm{LC}_{50}$ values of 4070 and $3570 \mathrm{ppm}$, respectively. These results revealed that visnagin, with one methoxy group, is more toxic against mites than khellin, which has two methoxy groups in its chemical structure. The results obtained suggest that chemical structures of monoterpenes and furanochromones with high bioactivity against mites can be used as potential parent 
structures for new acaricides as safe and alternative acaricidal agents through the integrated pest management programmes.

Table 2. Toxicity of monoterpenes and furanochromones against adult females of the twospotted spider mite, Tetranychus urticae (Koch) using the slide dip technique

\begin{tabular}{|c|c|c|c|c|}
\hline Compounds & $\begin{array}{c}\mathbf{L C}_{\mathbf{5 0}} \\
(\mathbf{p p m})\end{array}$ & Confidence limits for $\mathbf{L C}_{50}$ & Slope value & Toxicity index \\
\hline \multicolumn{5}{|l|}{ Monoterpenes: } \\
\hline Menthol & 640 & $(581.8-704.0)$ & 2.11 & 22.6 \\
\hline Linalool & 920 & $(836.4-1012.0)$ & 2.85 & 15.8 \\
\hline Thymol & 465 & $(430.5-502.2)$ & 2.35 & 31.2 \\
\hline Eugenol & 580 & $(537.0-626.4)$ & 1.82 & 25.0 \\
\hline Carvone & 575 & $(522.7-632.5)$ & 3.78 & 25.2 \\
\hline Camphor & 4250 & $(3863.6-4675.0)$ & 2.08 & 3.4 \\
\hline Limonene & NT & - & - & - \\
\hline Ocimene & NT & - & - & - \\
\hline \multicolumn{5}{|l|}{ Furanochromones: } \\
\hline Khellin & 4070 & $(3666.6-4517.7)$ & 2.62 & 3.1 \\
\hline Visnagin & 748 & $(686.2-815.3)$ & 3.27 & 19.4 \\
\hline \multicolumn{5}{|l|}{ Acaricide: } \\
\hline Vertimec & 145 & $(131.6-159.5)$ & 2.86 & 100 \\
\hline
\end{tabular}

NT = Non-toxic up to $10000 \mathrm{ppm}(1 \%)$.

Table 3. Toxicity of monoterpenes and furanochromones against adult females of the twospotted spider mite, Tetranychus urticae (Koch) using surface residue technique

\begin{tabular}{|c|c|c|c|c|}
\hline Compounds & $\begin{array}{c}\mathbf{L C}_{\mathbf{5 0}} \\
(\mathbf{p p m})\end{array}$ & Confidence limits for $\mathrm{LC}_{50}$ & Slope value & Toxicity index \\
\hline \multicolumn{5}{|l|}{ Monoterpenes: } \\
\hline Menthol & 580 & $(531.0-626.4)$ & 2.43 & 20.7 \\
\hline Linalool & 2150 & $(1954.5-2365.0)$ & 2.48 & 5.6 \\
\hline Thymol & 413 & $(382.4-446.0)$ & 2.93 & 29.0 \\
\hline Eugenol & 865 & $(720.8-1038.0)$ & 2.10 & 13.9 \\
\hline Carvone & 525 & $(486.1-567.0)$ & 2.60 & 22.8 \\
\hline Camphor & 3830 & $(3579.6-4098.1)$ & 1.92 & 3.1 \\
\hline Limonene & NT & - & - & - \\
\hline Ocimene & NT & - & - & - \\
\hline \multicolumn{5}{|l|}{ Furanochromones: } \\
\hline Khellin & 3570 & $(3367.9-3784.2)$ & 1.95 & 3.4 \\
\hline Visnagin & 540 & $(509.4-572.4)$ & 2.81 & 22.2 \\
\hline \multicolumn{5}{|l|}{ Acaricide: } \\
\hline Vertimec & 120 & $(104.3-138.0)$ & 2.68 & 100 \\
\hline
\end{tabular}

NT = Non-toxic up to $10000 \mathrm{ppm}(1 \%)$.

In conclusion, it can be stated that the terpene alcohol (menthol), the phenol compounds (thymol, eugenol), the monocyclic monoterpene ketone (carvone) and a furanochromone (visnagin) exhibited promising acaricidal efficacy against the two-spotted spider mite, T. urticae. The identification of novel active natural compounds against mites with potential new mode of action could increase the number of agrochemical agents and, subsequently, reduce the frequency of mite resistance phenomena to acaricides and providing alternative green pesticides of environmental safety.

\section{REFERENCES}

Bentley, M.D.; M.S. Rajab; A.R. Alford; M.J. Mendel and A. Hassanali (1988). Structure-activity studies of modified citrus limonoids as antifeedants for Colorado potato beetle larvae, Leptinotarsa decemlineata. Entomol. Exp. Appl., 49: 189-193.

Bouwmeester, H.J.; J. Gershenzon; M.C. Konings and R. Croteau (1998). Biosynthesis of the monoterpenes limonene and carvone in the fruit of caraway. Plant Physiol., 117: 901-912.

Bowers, W.S. (1985). Phytochemical resources for plant protection, p. 272-292. In: N.F. Janes, Ed., Recent Advances in the Chemistry of Insect Control. The Royal Society of Chemistry, Dorset Press, Dorchester, U.K. 
Brent, K.J. (1996). Pathways to success in fungicide research and technology. P. 3-15. In: Modern fungicides and antifungal compounds. H. Lyr, P.E. Russell and H.D. Sisler, eds. Intercept, Andover, Hans., U.K.

Dittrich, V. (1962). A comparative study of toxicological test methods on population of the two-spotted spider mite, Tetranychus telarius. J. Econ. Entomol., 55: 633-648 (1962).

Duke, S.O. (1986). Naturally occurring chemical compounds as herbicides. Rev. Weed Sci., 2: 15-44.

Eldoksch, H.A. and A.H. El-Sebae (2005). Plant natural products as a source of new and environmentally safe pesticides within JPM programmes. Egypt J. Agric. Res., 83 (3): 1127-1145.

Eldoksch, H.A.; A.H. Mansy and A.H. El-Sebae (1991a). Field evaluation of three synthetic pyrethroids and their mixtures with certain acaricides against mite population on cotton. Egypt. J. Appl. Sci., 6: 229-237.

Eldoksch, H.A. and F.M. Hassanein (2007). Efficacy of plant oils and their major monoterpenes in addition to powder formulation and seed cake of caraway oil on bacterial wilt incidence in potato. J. Pest Cont. \& Environ. Sci. 15 (2): 1-12.

Eldoksch, H.A.; H.I. Hussein; S.M.F. Ibrahim and E. Rodriguez (1997). Antifeedant and growth inhibitory activity of plant extracts and their major constituents colchicin, khellin and cardenolides on two cotton pests. J. Agric. Sci. Mansoura Univ., 22: 2431-2439.

Eldoksch, H.A.; M.A. Radwan and I.A. Abo-Elfadl (1991b). Antifeeding and synergistic activity of chenopodium and dill extracts and pure carvone on Spodoptera littoralis (Boisd.) (Lepidoptera : Noctuidae). Com. Sci. \& Dev. Res., 33: 249-263.

Eldoksch, H.A.; M.A. Shaaban and M.S. Abdel-Fattah (1996). Pyrrolizidine alkaloids isolated from Senecio vulgaris L. as larval feeding deterrents and growth retardants to the cotton leafworm, Spodoptera littoralis (Boisd.) (Lepidoptera : Noctuidae). Alex. Sci. Exch., 17: 57-67.

Eldoksch, H.A.; M.F. Atteia; S.M.H. and Abdel-Moity (2001). Management of brown leaf rust, Puccinia recondite of wheat using natural products and biocontrol agents. Bakistan J. of Biol. Sci., 4: 550-553.

Eldoksch, H.A. and S.M.H. Abdel-Moity (1997). Antifungal activity of some medicinal plant extracts against the soilborne fungi Rhizoctonia solani and Fusarium oxysporium. J. Agric. Sci. Mansoura Univ., 22: 28032811.

El-Sebae, A.H. (1987). Biotechnology in pest control with special reference to natural products, $2^{\text {nd }}$ Nat. Conf. of Pest \& Dis. of Veg. \& Fruits, Ismailia, p. 19-38 (1987).

El-Sebae, A.H.; H.A. Eldoksch; A.S.M. Marei and F.I. Moustafa (1978). Toxicity of certain pesticides and their combinations against the red mite species Tetranychus cucurbitacearum. Alex. J. Agric. Res., 26: 453-460.

Finney, D.J. (1971). Probit analysis. $3^{\text {rd }}$ Ed. Cambridge University Press, Cambridge, pp. 318 (1971).
Hamaad, R.F.M.; H.A. Eldoksch; A.M. Abdel-Samed and N.M. Abdel-Moein (2008). Effect of Essential oils and a thymol formulation for controlling Varroa destructor in honey bee (Apis mellifera) colonies. Egypt J. Agric. Res., 86 (3): 951-961.

Hassanein, F.M. and H.A. Eldoksch (1997). Antibacterial action of carvone and some plant extracts on certain phytopathogenic bacteria and pathogenicity of Agrobacterium tumefaciens. Alex. J. Agric. Res., 42: 127-136.

Hosny, A.H.; A.Y. Keratum; M.M.F. El-Naggar and R.I. Magouz (2003). Laboratory and field evaluation of environmentally safe chemicals against the two-spotted spider mite Tetranychus urticae (Koch.) and its predatory mite Amblyseius gossipi (El-Badry). J. Pest Cont. \& Environ. Sci., 11: 87-104.

Ismail, I. and F.M. Hoda (1985). Effect of nineteen acaricides on the green spider mite, Tetranychus urticae Koch. infesting soyabean plants at Gimmeza, Gharbia Governorate, Egypt. Egypt's National Conference of Entomology, Dec. 6-9, 1982. (Bull. Ent. Soc. Egypt, Econ., Ser., 5: 787-793 (1985).

Litchfield, J.T.Jr and F. Wilcoxon (1949). A simplified method of evaluating dose-effect experiments. J. Pharmacol. and Exp. Therap., 96: 99-113.

Meisner, J.; A. Fleischer and C. Elzick (1982). Phagodeterrency induced by carvone in the larvae of Spodoptera littoralis (Lepidoptera : Noctuidae). J. Econ. Entomol., 75: 462-466.

Meisner, J.; M. Weissenberg; D. Palevitch and N. Aharonson (1981). Phagodeterrency induced by leaves and leaf extracts of Catharanthus roseus in the larvae of Spodoptera littoralis. J. Econ. Entomol., 74: 131-135.

Miresmailli, S.; R. Bradbury and M.B. Isman (2006). Comparative toxicity of Rosmarinus officinalis L. essential oil and blends of its major constituents against Tetranychus urticae Koch (Acari : Tetranychidae) on the two different host plants. Pest Manag. Sci., 62: 366-371.

Naigre, R.; P. Kalck; C. Roqus; I. Roux and G. Michel (1996). Comparison of antimicrobial properties of monoterpenes and their carbonylated products. Planta Med., 62: 275277.

Osman, A.A.; G.I. Zohdi and S.M. Abo-Korah (1985). Synthetic pyrethroids and their role against mites on cotton. Bull. Ent. Soc. Egypt, Econ. Ser., 5: 795-802.

Pillmoor, J.B.; K. Nright and A.S. Terry (1993). Natural products as a source of agrochemicals and leads for chemical synthesis. Pestic. Sci., 39: 131-140.

Saleh, M.A.; N.M. Abdel-Moein and N.A. Ibrahim (1984). Insect antifeeding azulene derivative from the brown alga Dictyota dichotoma. J. Agric. Food Chem., 32: 14321434.

Sivropoulou, A.; S. Kokkini; T. Lanaras and M. Arsenakis (1995). Antimicrobial activity of mint essential oils. J. Agric. Food Chem., 43: 2384-2388. 
Stendel, A. and R. Fuchs (1984). In "Acarology VI" Ed. by

D.A. Griffiths and C.E. Bowman, Ellis Horwood,

Chiechester, UK, 2: 1252-1255 (1984).

\section{الملخص العربي}

\section{دراسة فعالية المستخلصات النباتية وبعض مر كباتما التربينية النقية كمبيدات أكاروسية ضد الحلم

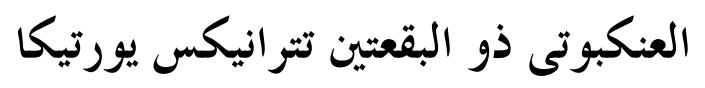

حمدى على الدكش، فريدة أحمد عياد، عبدالخالق حامد السباعى

ولقد أظهرت النتائج أيضاً أن المركب كارفون وهو تـــبين أحادى كيتونى ذو حلقة واحدة أعطى نشاط عالى ضد الأكاروس

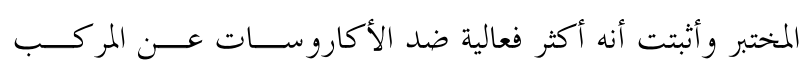

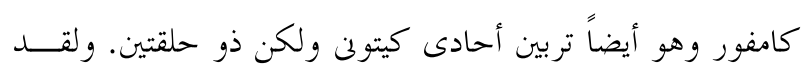

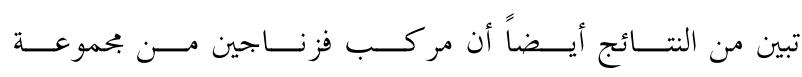

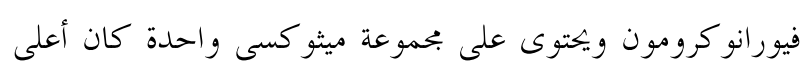

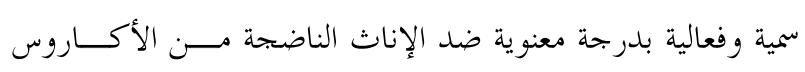

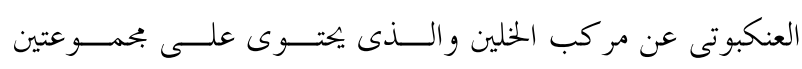
ميثو كسى فن تركيبه الكيماوى. وعلى ذلك فإن الجزيئات التربينية

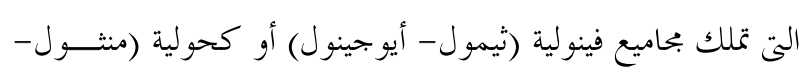
لينالول) أو كيتون ذو حلقة واحدة (كارفون) ومركب الفيزناجين

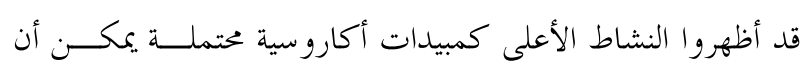

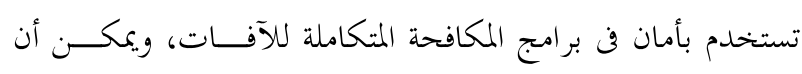

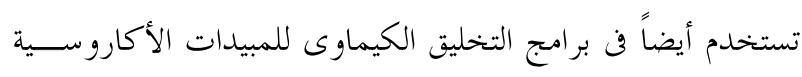

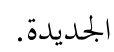

تم دراسة النشاط السام لبعض المستخلصات النباتية المعزولــــة

من النباتات الطبية والعطرية وبعض من مركباتا الأساسية التربينيــة

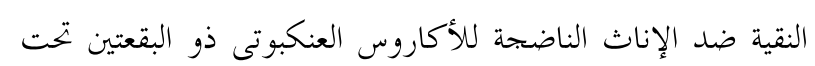

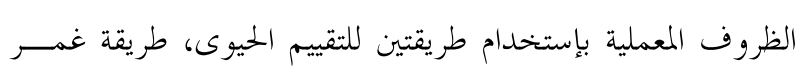

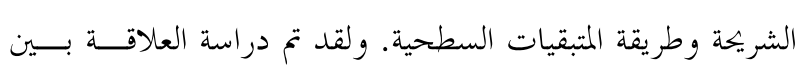
التركيب الكيماوى والفعالية للمواد التربينية كمبيدات أكاروســـية.

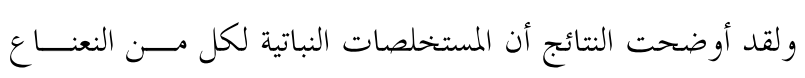

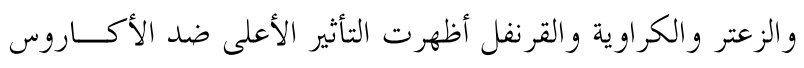
العنكبوتى وتبعه في الفعالية مستخلص الكينوبوديوم و الفيزناجا بينما أعطت مستخلصات الريحان الحلو والكافور التأثير الأقل نسبياً. ومن المركبات التربينية المختبرة وجد أن التربينات الأحادية ذات التركيب المحتوى على هيدروكربونات مثل الليمونين والأوسيمين تكون غير فعالة على الأكاروس المختبر بينما المركبات التربينية الأحادية مـــن فئن

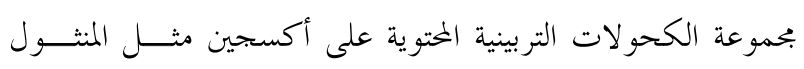
و اللينالول قد أظهرت تأثير عالى كمبيدات أكاروسية. 